\title{
Procjena zdravstvenog stanja stanovnika Primorsko-goranske županije
}

\section{Assessment of the health status of the residents in Primorsko- Goranska County}

\author{
Suzana Jankovićc ${ }^{1,2 *}$, Ljiljana Beg Zrakić1 ${ }^{1}$ Đulija Malatestinić ${ }^{2}$, Sanjin Pugel ${ }^{1}$
}

${ }^{1}$ Nastavni zavod za javno zdravstvo Primorsko-goranske županije, Rijeka, Hrvatska

${ }^{2}$ Sveučilište u Rijeci, Medicinski fakultet, Rijeka, Hrvatska
Sažetak. Procjenom zdravstvenog stanja stanovnika data je slika zdravlja Primorsko-goranske županije, na temelju koje se mogu identificirati i ocijeniti zdravstvene potrebe stanovništva. Prilikom procjene zdravlja i zdravstvenih potreba stanovnika Županije korištena je rutinska zdravstvena i demografska statistika i analizirani su demografski i zdravstveni pokazatelji. U istraživanju zdravstvenih pokazatelja korišteni su podatci Svjetske zdravstvene organizacije u strategiji unaprjeđenja zdravlja „Zdravlje za sve u 21. stoljeću” i podatci mortalitetne statistike Hrvatskog zavoda za javno zdravstvo, a analiza pokazatelja provodila se deskriptivnom statističkom metodom, prvenstveno komparativnom analizom. Razina prikaza i interpretacije podataka jest Županija, odnosno njezine četiri podregionalne cjeline.

Doprinos je ovoga rada podrška donositeljima odluka u promicanju, održavanju i unaprjeđenju zdravlja u zajednici, odnosno kvalitete življenja stanovništva na području Županije u cijelosti. Ocjena može poslužiti za odabir novih prioriteta, kao i podloga za izradu smjernica budućih intervencija u zajednici.

Ključne riječi: demografija; uzroci smrti; vitalna statistika; zdravstveno stanje

Abstract. Assessing the health status of Primorje-Gorski Kotar County residents a picture of the health of the county in the health context will be obtained. This would identify and evaluate the health needs of the population. The health and health needs of Primorje-Gorski Kotar County residents were assessed using routine health and demographic statistics. For Primorje-Gorski Kotar County, demographic and health indicators were analyzed. In the research of health indicators, the data of the World Health Organization from the health improvement strategy "Health for all in the $21^{\text {st }}$ century" and the data of mortality statistics of the Croatian Institute of Public Health were used. The analysis of the indicators will be performed by a descriptive-statistical method, primarily by comparative analysis. The level of representation and interpretation of data was the County and its four subregional units. The contribution of this paper consists of supporting decision-makers to promote, maintain and improve community health and quality of living in the County on the basis of measuring the health needs of the population. The assessment could serve for selecting new priorities as well as the basis for developing guidelines for future interventions in the community.

Key words: cause of death; demography; health status; vital statistics

\author{
*Dopisni autor: \\ Doc. dr. sc. Suzana Janković, dr. med. \\ Nastavni zavod za javno zdravstvo \\ Primorsko-goranske županije, \\ Krešimirova 52a, Rijeka \\ E-mail: suzana.jankovic1@gmail.com
}




\section{UVOD}

Polazište u ocjeni zdravstvenog stanja stanovnika Primorsko-goranske županije predstavlja definicija zdravlja prema Svjetskoj zdravstvenoj organizaciji (SZO) koja definira zdravlje kao stanje potpunog tjelesnog, duševnog i socijalnog blagostanja, a ne samo odsutnost bolesti i iznemoglo$\mathrm{sti}^{1}$.

Definiranje zdravlja posebno je složeno danas, kada je naglasak medicinske i zdravstvene zaštite pomaknut sa smanjenja smrtnosti i produžavanja života, prema unaprjeđenju zdravstva i većoj kvaliteti života. Bolje razumijevanje zdravstvenog stanja populacije i životnih navika, kako bi ljudi bili zdraviji, radili duže i kvalitetnije, zahtijeva kontinuirano praćenje determinanti zdravlja, što je neophodno kako bi se razvile intervencije i programi koji će očuvati zdravlje i omogućiti onima narušenog zdravlja da nastave biti produktivni članovi zajednice ${ }^{2}$.

U svakodnevnom životu okruženi smo važnim determinantama zdravlja (socijalne, ekonomske, kulturalne okolnosti, stilovi života, ponašanje pojedinca...) tako da se značajan dio zdravstvenih potreba ne može zadovoljiti isključivo putem zdravstvenog sustava.

Pokazatelji zdravstvenog stanja populacije prikupljeni su uvidom u dostupne podatke koji se generiraju unutar zdravstvenog informacijskog sustava temeljem rutinske zdravstvene i demografske statistike.

Prikazane su sljedeće skupine pokazatelja:

a) demografski pokazatelji - distribucija stanovništva po spolu i dobi, osnovni kontingenti stanovništva, vitalno-statistički pokazatelji

b) pokazatelji zdravstvenog stanja - pokazatelji mortalitetne i morbiditetne statistike, očekivano trajanje života na dan rođenja te prijevremene smrti i izgubljene godine života.

U socijalno-medicinskim analizama stanovništvo ima vrlo važnu ulogu. Stanovništvo čine ljudi koji na određenom području stalno stanuju i borave. Ukupno stanovništvo čine svi stanovnici koji trajno borave u zemlji najmanje jednu godinu.

Demografski podatci prikupljaju se popisima stanovništva koji se provode svakih deset godina, svake prve godine u desetljeću te prijavama ži- votnih događaja (matične knjige rođenih, vjenčanih, umrlih, podatci Ministarstva unutarnjih poslova i sl.). Informacije su standardizirane i na taj su način podatci međunarodno usporedivi ${ }^{3}$. Brojčano kretanje i dobna struktura stanovništva određena je rađanjem i umiranjem (prirodni procesi) i migracijom stanovništva (socijalni proces). Starenje stanovništva jedan je od vodećih populacijskih problema stanovnika Primorsko-goranske županije. Uzrok pojave je nizak natalitet $\mathrm{i}$ povećanje očekivanog trajanja života.

Populacija u Primorsko-goranskoj županiji stari, s udjelom starijih od 65 godina 18,91\%. Stopa nataliteta opada, a mortaliteta je u porastu, što uzrokuje depopulaciju u Županiji. Kao i u većini razvijenih zemalja, vodeći su uzroci smrti kardiovaskularne bolesti, a na drugome su mjestu novotvorine, po kojima smo znatno lošiji od Europske unije, ali i od Republike Hrvatske. Ova dva vodeća uzroka smrti imaju udio od oko $75 \%$ u svim uzrocima.

Glavnina stanovništva Županije koncentrirana je u gradu Rijeci. Otoci su slabije nastanjeni. Priobalje je zapravo prsten oko grada Rijeke i prilično je gusto naseljeno. U Gorskom kotaru oduvijek je bilo skuplje i teže živjeti pa je on danas najslabije razvijena regija i, nažalost, polako izumire.

Pokazatelji zdravstvenog stanja stanovništva uglavnom su iz domene „negativnog“ zdravlja (morbiditet, mortalitet). Dobiveni su kao rezultat rutinske zdravstvene i demografske statistike temeljem sljedećih pozitivnih zakonskih propisa: Zakona o zdravstvenoj zaštiti, Zakona o državnoj statistici, Programa statističkih istraživanja, Godišnjeg provedbenog plana statističkih aktivnosti Republike Hrvatske.

Podatci u radu prikazani su u relativnim i apsolutnim brojevima (postotcima) u linearnim grafičkim prikazima i tablicama. Za obradu je korišten Microsoft Office, program Excel 2016.

Kao glavni izvori podataka korištene su:

- agregirane tablice statističkih ljetopisa Državnog zavoda za statistiku (DZS), Hrvatskog zavoda za javno zdravstvo (HZJZ), Nastavnog zavoda za javno zdravstvo Primorsko-goranske županije (NZJZ PGŽ-a), bilteni, publikacije 
- baze podataka European Health for All Database (EHFA - DB), baza umrlih osoba HZJZ-a za Primorsko-goransku županiju, Hrvatskog zavoda za zapošljavanje.

U postupku ocjene zdravstvenog stanja stanovništva pokazatelji mortalitetne statistike iz programa Svjetske zdravstvene organizacije „Health for All" uspoređuju zdravstveno stanje populacije između zemalja Europske unije. Tako su za usporedbu sa zdravstvenim stanjem stanovnika Primorsko-goranske županije odabrane zemlje Europske unije (EU average) i Hrvatska u desetogodišnjem razdoblju od 2009. do 2018. Za komparaciju su korištene dobno standardizirane stope jer grube stope mogu biti odraz razlika u dobnoj strukturi stanovništva, a ne u veličini pojave. Kao izvor podataka korištena je Baza umrlih 2009.-2018. HZJZ-a i WHO/Europe, European HFA - DB. Uzrok smrti na razini Županije prikazan je i krutim stopama po spolu za petogodišnje razdoblje.

Kao baza za izračun odabranih indikatora za Primorsko-goransku županiju, za 2018. godinu koristili su se podatci iz popisne 2011. godine, stoga što se službene procjene stanovnika sredinom svake godine donose samo na ukupan broj stanovnika, ali ne i na njihov sastav, što nije dostatno za izradu pokazatelja. Od složenijih pokazatelja zdravstvenog stanja stanovnika prikazano je očekivano trajanje života na dan rođenja te prijevremene smrti i izgubljene godine života.

\section{REZULTATI}

\section{Demografski pokazatelji}

Ukupno kretanje stanovništva Županije i njezinih subregija u razdoblju od 1991. do 2018. godine pokazuje značajno smanjenje broja stanovnika. Broj stanovnika pao je s 323130 u 1991. godini na 283405 u 2018. godini, što predstavlja relativno smanjenje od $12,3 \%$. Smanjenje je zamjetno i u međupopisnom razdoblju od 1991. do 2001. godine kada je depopulacijska stopa iznosila -5,5 \%, čime Županija započinje razdoblje intenzivne depopulacije, koje traje sve do danas. Navedena stopa intenzitetom je osjetno viša od depopulacije iz razdoblja od 2001. do 2011. godine, kada je ona bila gotovo dvostruko niža i iznosila je $-3,1 \%$. Depopulacijska stopa od $-4,3 \%$ zabilježena je u razdoblju od 2011. do 2018. godine. U promatranom razdoblju od gotovo tridesetak godina možemo konstatirati da grad Rijeka i sve jedinice lokalne samouprave u Gorskom kotaru bilježe smanjenje broja stanovnika, dok je povećanje zamjetno u priobalju i na otocima. Pad stanovništva izrazit je u gradu Rijeci, gdje se broj

Tablica 1. Osnovni kontingenti stanovništva Primorsko-goranske županije po subregijama

\begin{tabular}{|c|c|c|c|c|c|c|c|c|}
\hline \multirow{2}{*}{ Područje } & \multirow{2}{*}{ Svega } & \multicolumn{4}{|c|}{ DOBNE SKUPINE } & \multirow{2}{*}{$\begin{array}{c}\text { Prosječna } \\
\text { starost }\end{array}$} & \multirow{2}{*}{$\begin{array}{c}\text { Index } \\
\text { starenja* }\end{array}$} & \multirow{2}{*}{$\begin{array}{c}\text { Koef. ukupne } \\
\text { dobne } \\
\text { ovisnosti** }\end{array}$} \\
\hline & & $0-14$ & $0-19$ & $20-64$ & 65 i više & & & \\
\hline RIJEKA & 128624 & 14965 & 20733 & 82503 & 25388 & 44,5 & 169,8 & 45,7 \\
\hline struktura & 100 & 11,63 & 16,12 & 64,14 & 19,74 & & & \\
\hline PRIOBALJE & 104854 & 14214 & 19196 & 67853 & 17805 & 42,2 & 136,2 & 44 \\
\hline struktura & 100 & 13,56 & 18,31 & 64,71 & 16,98 & & & \\
\hline отосІ & 39706 & 5203 & 7223 & 24853 & 7630 & 43,1 & 146,9 & 47,8 \\
\hline struktura & 100 & 13,1 & 18,19 & 62,59 & 19,22 & & & \\
\hline GORSKI KOTAR & 23011 & 2585 & 3607 & 14223 & 5181 & 45,8 & 190,5 & 50,9 \\
\hline struktura & 100 & 11,23 & 15,68 & 61,81 & 22,52 & & & \\
\hline ŽUPANIJA & 296195 & 36967 & 50759 & 189432 & 56004 & 43,9 & 155,3 & 45,7 \\
\hline struktura & 100 & 12,48 & 17,14 & 63,96 & 18,91 & & & \\
\hline
\end{tabular}

* Pokazuje broj stanovnika starih 60 i više godina prema broju stanovnika starih od 0 do 19 godina

** Pokazuje stupanj opterećenosti stanovništva radnog kontingenta mladima i starima

Izvor: Državni zavod za statistiku, Popis stanovništva 2011. 
stanovnika sa 144043 u 2001. godini smanjuje na 128624 stanovnika, odnosno prema procjeni, u 2018. godini na 117 415. Time demografsko značenje Rijeke kao sjedišta Županije značajno pada. Depopulacijska stopa iznosila je $8,7 \%$ u razdoblju od 2011. do 2018. godine, odnosno $10,7 \%$ u razdoblju od 2001. do 2011. godine. Smanjenje je snažnije od depopulacije cjelokupne Županije ${ }^{4-7}$. Dobno-spolna struktura stanovništva, kao posljedica dugogodišnjeg smanjivanja nataliteta u Primorsko-goranskoj županiji, vidljiva je u dobnim piramidama koje su razorene u dječjoj bazi i podsjećaju na urne (slika 1,2).

Sve je više stanovnika u dobnim skupinama 60 i više godina pa se struk piramide pomiče prema gore. Riječ je o regresivnom tipu starosne strukture - baza piramide uža je od njezinog središnjeg dijela. Stope nataliteta na razini su mortaliteta ili čak i niže. To ukazuje na nizak, opadajući prirodni priraštaj stanovnika i na proces depopulacije ${ }^{8}$.

Prema rezultatima popisa stanovništva iz 2011. godine, u Primorsko-goranskoj županiji živi 296 195 stanovnika (tablica 1). U Županiji živi više žena $(51,7 \%)$ nego muškaraca (48,3 \%). Udio pučanstva starog 65 i više godina iznosi 18,91\%. Udio pučanstva od 0 do 39 godina u ukupnom pučanstvu je $43,4 \%$, što označava veliko starenje populacije (udio manji od $60 \%)^{8}$.

U 2018. godini nastavlja se kontinuirano starenje stanovništva. Stanovništvo Republike Hrvatske, s prosječnom starošću od 43,3 godine, ubraja se među najstarije u Europi. Prosječna starost stanovnika Županije još je veća - 43,9 godina.

Procesu starenja uvelike pridonosi višegodišnje opadanje udjela mladog stanovništva (0 - 19 godina) u ukupnom stanovništvu. Spomenuti udio u Primorsko-goranskoj županiji, prema procjeni DZS-a 2018. godine, iznosi 16,55 \% i manji je od državnog prosjeka (19,6 \%). Udio kontingenta 65 i više godina u ukupnom stanovništvu iznosio je 23,22 \% i znatno je veći od 18,91 \% koliko je iznosio na službenom popisu 2011. godine. Udio radno aktivnog stanovništva iznosio je 60,22\% i također je nešto manji od udjela u 2011. godini kada je iznosio 63,96 \%

Podatci o prirodnom kretanju stanovništva jedan su od pokazatelja stvarnih demografskih procesa u Županiji (slika 3).

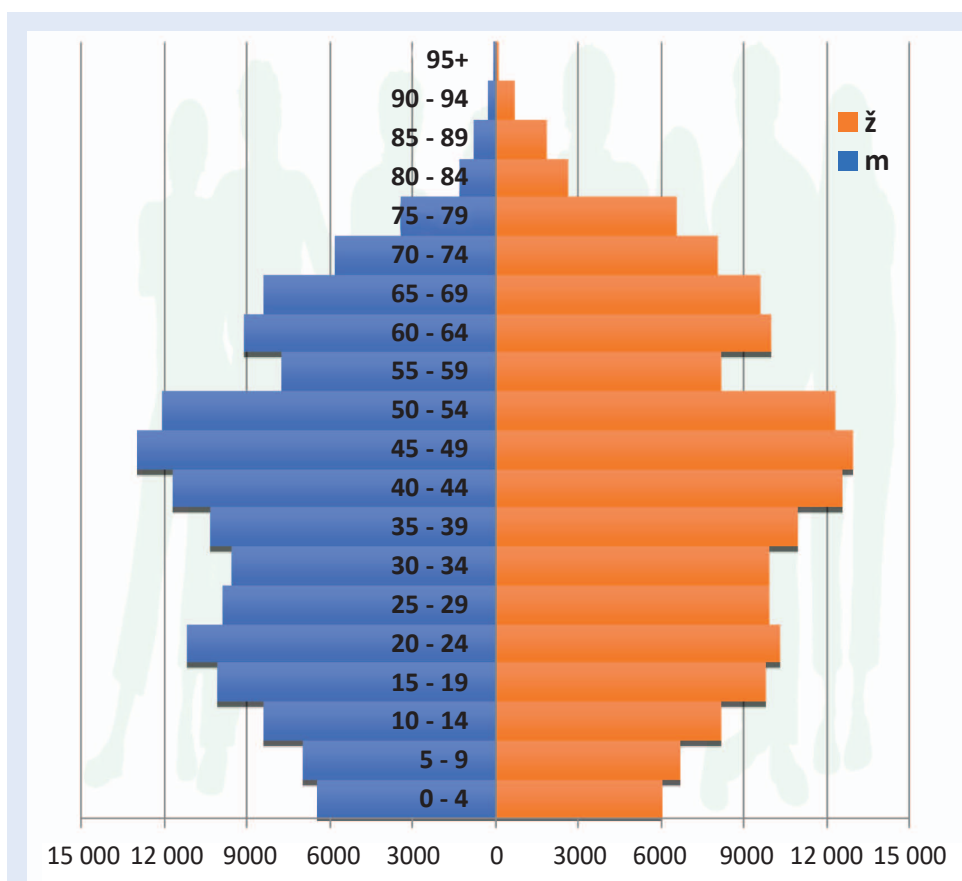

Slika 1. Dobna piramida stanovništva Primorsko-goranske županije po popisu 2001. godine

Izvor: NZJZ PGŽ-a, Zdravstveno-statistički ljetopis PGŽ-a za 2018. godinu

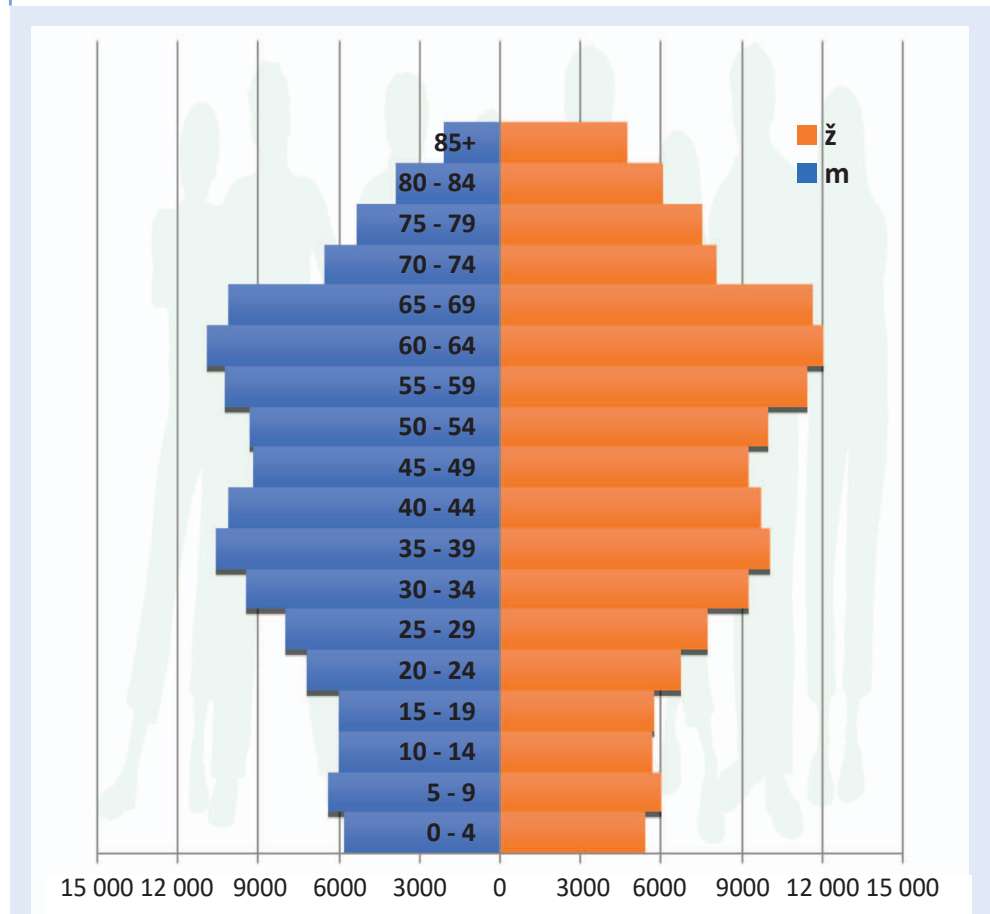

Slika 2. Dobna piramida stanovništva Primorsko-goranske županije po popisu 2011. godine

Izvor: NZJZ PGŽ-a, Zdravstveno-statistički ljetopis PGŽ-a za 2018. godinu 


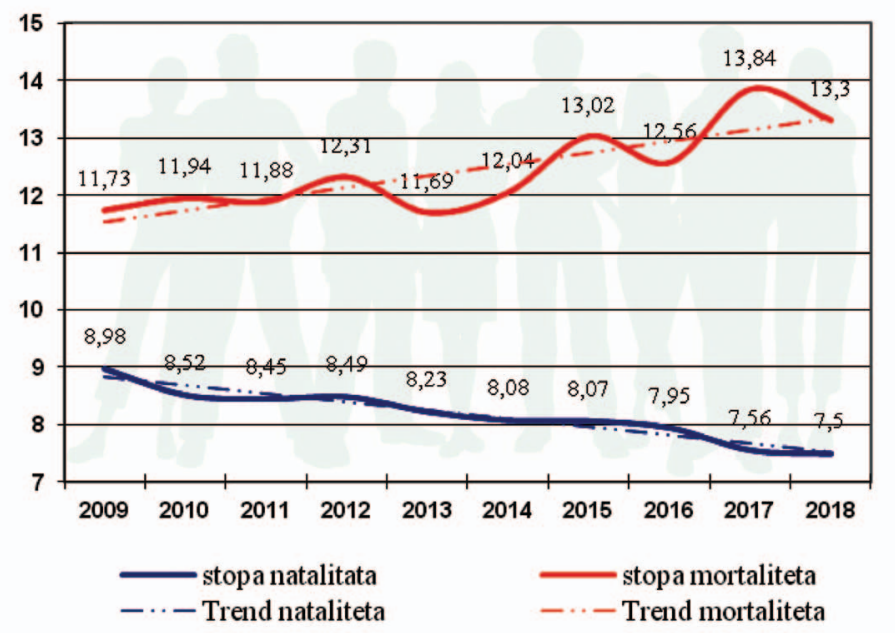

Slika 3. Prirodno kretanje stanovništva Županije 2009. - 2018.

Izvor: Državni zavod za statistiku

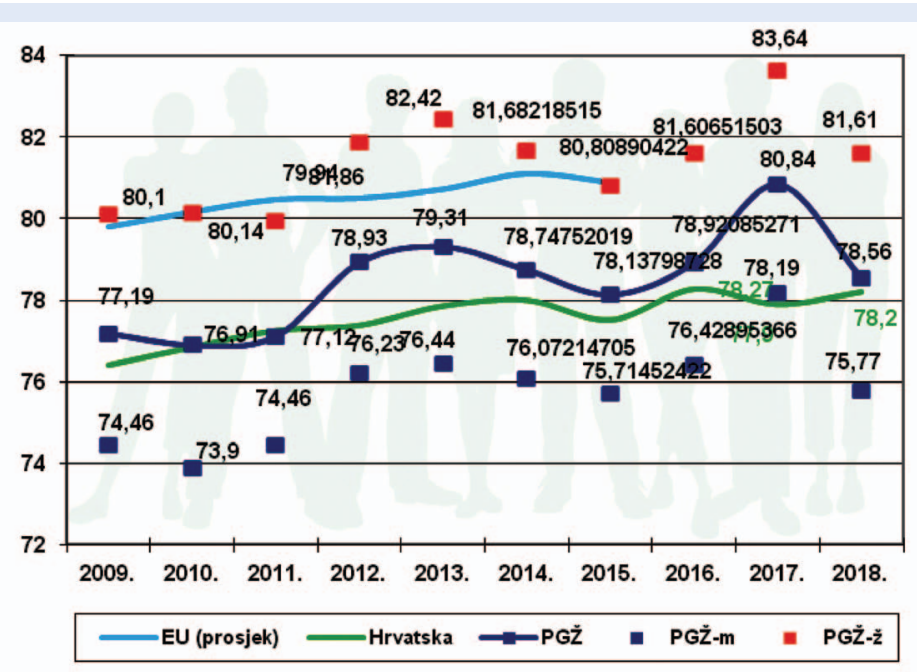

Slika 4. Očekivano trajanje života na dan rođenja

Izvor: European health for All database, HZJZ/ baza umrlih PGŽ-a

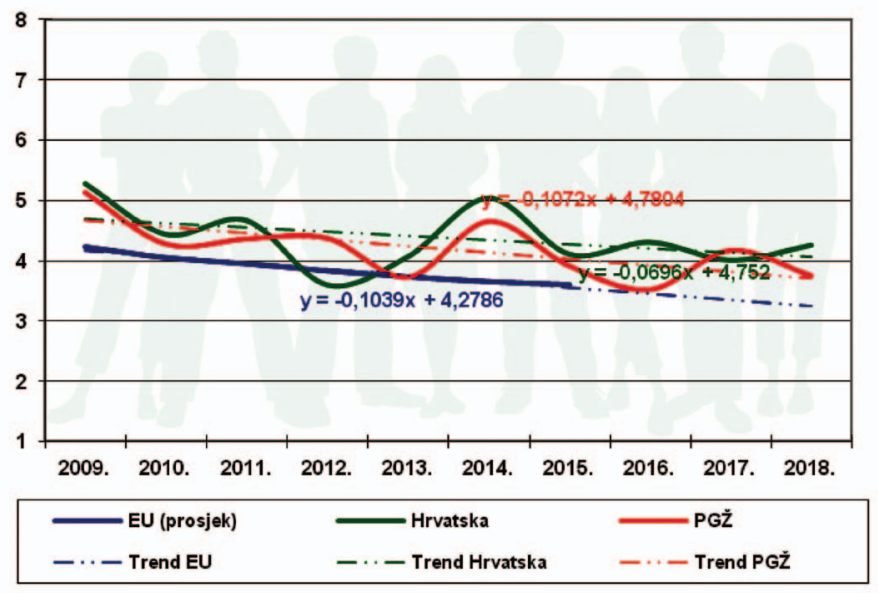

Slika 5. Standardizirana stopa dojenačke smrtnosti na 1000 živorođenih Izvor: European health for All database, HZJZ/ baza umrlih PGŽ-a
U promatranom desetogodišnjem razdoblju prirodno kretanje stanovništva Županije, kao i svih njezinih subregija, bilo je negativno, što znači da je umiranje bilo učestalija pojava od rađanja. U tom su razdoblju samo tri jedinice lokalne samouprave imale pozitivnu prosječnu stopu prirodnog priraštaja stanovnika (Viškovo 5,5 \%o, Kastav 0,8 \%o, i Omišalj 4,2 \%o). Krk je imao nultu stopu priraštaja. U ostalim jedinicama došlo je do denataliteta. Uzrok takvom stanju prvenstveno leži u niskom natalitetu i visokom mortalitetu (velik udio starije populacije). Najmanju prosječnu stopu prirodnog priraštaja u promatranom razdoblju imao je, očekivano, Gorski kotar (-10,5 \%o), a najveću priobalje $(-2,1 \%)^{9-18}$. Negativno prirodno kretanje u proteklih deset godina pokazuje i vitalni indeks koji stavlja u omjer broj živorođenih u odnosu na broj umrlih. Od svih promatranih jedinica, najniži vitalni indeks zabilježen je u Skradu u kojem jedno rođenje prate četiri umiranja. Vitalni indeks u kojem je broj živorođenih veći od broja umrlih zabilježen je samo u tri jedinice lokalne samouprave: Viškovu, Omišlju i Kastvu ${ }^{4-18}$.

\section{Zdravstveni pokazatelji}

Odabrani zdravstveni pokazatelji za usporedbu, iz EHFA-DB programa, iz područja su mortalitetne statistike (podatci vitalne statistike najkvalitetniji su rutinski prikupljeni podatci) i izraženi su u standardiziranim stopama. Za usporedbu sa zdravstvenim stanjem stanovnika Primorsko-goranske županije odabrane su zemlje Europske unije (EU average) i Hrvatska. Kao baze za izračun odabranih indikatora za Primorsko-goransku županiju i Hrvatsku korišteni su podatci iz popisne 2011. godine. Uzrok smrti na razini Županije prikazan je i krutim stopama.

Očekivano trajanje života u Primorsko-goranskoj županiji na dan rođenja u 2018. godini iznosi 81,6 za žene i 75,8 za muškarce, ukupno za oba spola 78,6 , dok je očekivano trajanje života u Republici Hrvatskoj 78,2, dakle nešto niže od Županije (slika 4).

Građanima Europe, prema posljednjem dostupnom podatku HFA DB-a iz 2015. godine, očekivano trajanje života nešto je duže -81 godinu ${ }^{19,20}$. Jedan od tradicionalno najčešće korištenih pokazatelja zdravstvenog stanja stanovništva, učinko- 
vitosti zdravstvene zaštite i dostignutog životnog standarda uopće jest mortalitet dojenčadi. Mortalitet dojenčadi Primorsko-goranske županije u razdoblju od 2009. do 2018. bilježi padajući trend, iako sporije od željenog (slika 5).

Raspon kretanja mortaliteta dojenčadi u zemljama Europske unije kreće se od 4,5/1000 živorođene djece u 2007. godini, pa do 3,6/1000 u 2016. godini. Županijska stopa dojenačke smrtnosti u 2018. godini iznosila je 3,76/1000 i neznatno je niža od republičke 4,25/1000 ${ }^{19,20}$.

Standardizirana stopa smrtnosti, odnosno trend umiranja stanovnika na određenom području, za razdoblje od 2009. do 2018. pokazuje da je europska stopa znatno niža od hrvatske i županijske stope te je 2015. iznosila 561/100 000 (slika 6).

Županijska stopa niža je od republičke i najvišu je vrijednost imala prve promatrane godine $(722,12 / 1000)$. Sve tri stope imaju silazni trend $d^{19,20}$. Kardiovaskularne bolesti vodeći su uzrok smrti nešto manje od polovine svih umrlih u Županiji, Republici Hrvatskoj i zemljama Europske unije u vremenskom razdoblju od 2009. do 2018. godine. Trend smrtnosti od kardiovaskularnih bolesti u dobnoj skupini od 0 do 64 u promatranom razdoblju konstantno opada, pri čemu kod stanovnika Županije sličnom stopom i progresijom kao i kod stanovnika Europske unije (slika 7).

Razina stope smrtnosti od kardiovaskularnih bolesti stanovnika Hrvatske također ima trend pada, iako je znatno viša od županijske i europske.

Županijska stopa smrtnosti 2012. bilježi rast $(47,0 / 100000)$ pa lagano pada do 2017. $(42,9 / 100000)$, da bi u 2018. godini dosegla najnižu vrijednost u promatranom desetogodišnjem razdoblju $(35,8 / 100000)^{19,20}$. Prema spolu, od kardiovaskularnih bolesti umire više žena nego muškaraca, djelomično i zato jer žene duže žive ${ }^{20}$. Ishemijske bolesti srca vodeći su uzrok smrti unutar kardiovaskularnih bolesti. I ovdje su stope kod žena veće ${ }^{20}$.

Unutar skupine kardiovaskularnih bolesti, nakon ishemijskih bolesti srca, za većinu su smrti odgovorne cerebrovaskularne bolesti. Kod stanovnika Županije u promatranom razdoblju razina je smrtnosti, kao i ukupnih kardiovaskularnih bolesti, nešto viša od europske i niža od republič$\mathrm{ke}^{19,20}$.

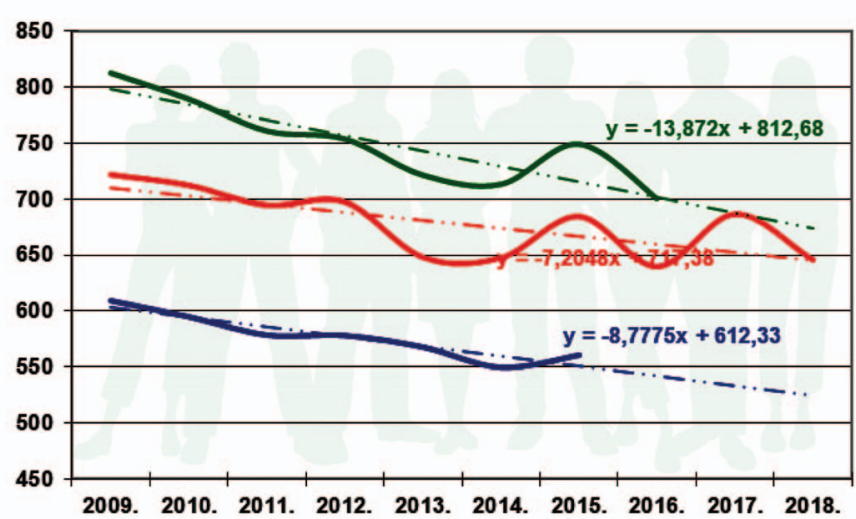

\begin{tabular}{|lll|}
\hline & - Hrvatska & - PGŻ \\
\cline { 3 - 3 } EU (prosjek) & $-\cdots-$ Trend Hrvatska & $-\cdots-$ Trend PGŻ \\
\hline
\end{tabular}

Slika 6. Standardizirana stopa smrtnosti na 100000 stanovnika Izvor: European health for All database, HZJZ/ baza umrlih PGŽ-a

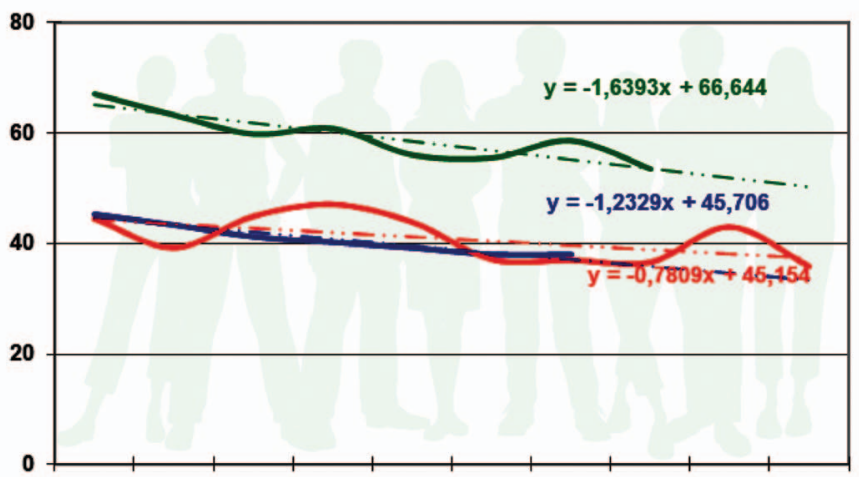

2009. 2010. 2011. 2012. 2013. 2014. 2015. 2016. 2017. 2018.

\begin{tabular}{|c|c|c|}
\hline —UU (prosjek) & Hrvatska & PGŻ \\
\hline - $\cdots-$ Trend EU & - $\cdots-$ Trend Hrvatska & $-\cdots-$ Trend PGŻ \\
\hline
\end{tabular}

Slika 7. Standardizirana stopa smrtnosti od kardiovaskularnih bolesti za dob od 0 do 64 godine na 100000 stanovnika

Izvor: European health for All database, HZJZ/ baza umrlih PGŽ-a

Novotvorine su drugi vodeći uzrok smrti, odgovoran za približno četvrtinu svih umrlih u Republici Hrvatskoj i Primorsko-goranskoj županiji. U zemljama Europske unije, od početka promatranja, razina smrtnosti od novotvorina u stalnom je opadanju (2009. je iznosila 170/100 000, a 2015. $159,9 / 100000)$ i znatno je niža od republičke i županijske stope (slika 8). 


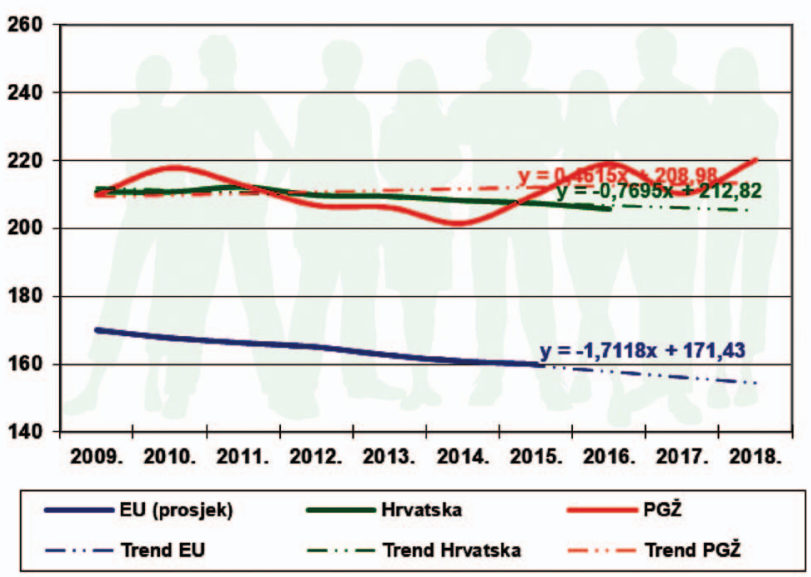

Slika 8. Standardizirana stopa smrtnosti od novotvorina na 100000 stanovnika

Izvor: European health for All database, HZJZ/ baza umrlih PGŽ-a

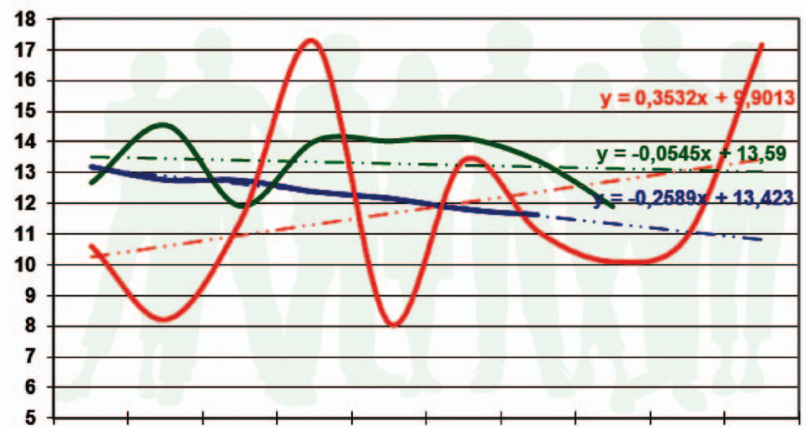

2009. 2010. 2011. 2012. 2013. 2014. 2015. 2016. 2017. 2018.

\begin{tabular}{|lll|}
\hline EU (prosjek) & - Hrvatska & - PGŻ \\
\cline { 2 - 3 }$-\cdots-$ Trend EU & $-\cdots-$ Trend Hrvatska & $-\cdots-$ Trend PGŻ \\
\hline
\end{tabular}

Slika 9. Standardizirana stopa smrtnosti od zloćudnih novotvorina dojke za dob od 0 do 64 godine na 100000 žena

Izvor: European health for All database, HZJZ/ baza umrlih PGŽ-a

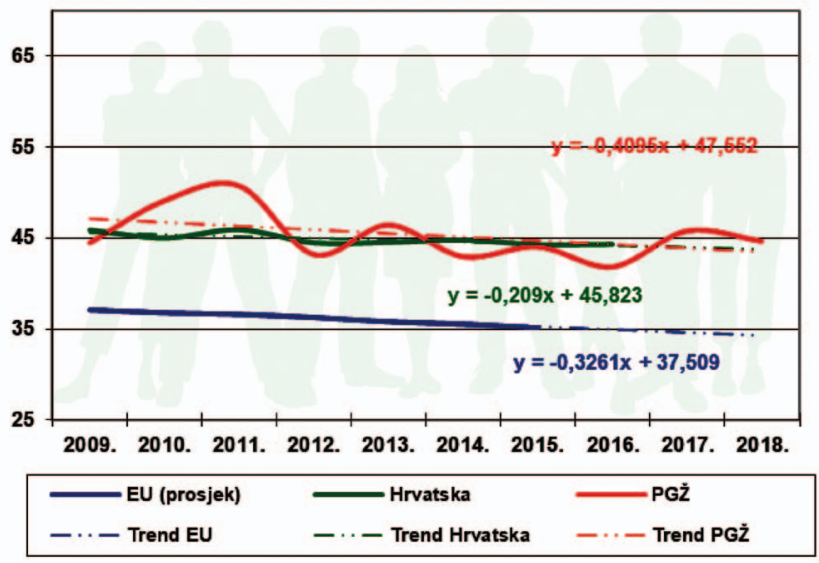

Slika 10. Standardizirana stopa smrtnosti od zloćudnih novotvorina dušnika, dušnica i pluća na 100000 stanovnika

Izvor: European health for All database, HZJZ/ baza umrlih PGŽ-a
Republička stopa smrtnosti također ima silazni trend i kreće se od 210,9/100 000 u 2009. godini do 205,8/100 000 u 2016. godini. Standardizirana stopa u Primorsko-goranskoj županiji isprepletena je s republičkom stopom. Najveću vrijednost doseže u zadnjoj promatranoj, 2018. godini i ona iznosi 220,3/100 000.

Stopa smrtnosti od zloćudnih novotvorina svih sijela po spolu je različita, tako da je u 2018. godini gruba stopa smrtnosti u Primorsko-goranskoj županiji iznosila 397/100 000 (477/100 000 za muškarce i 322/100 000 za žene) $)^{20}$.

U zemljama Europske unije u promatranom razdoblju (2009. - 2018.) vidljiv je silazni trend smrtnosti od novotvorina dojke (slika 9).

U Primorsko-goranskoj županiji stopa je uzlazna. Prisutne su oscilacije zbog manjeg broja stanovnika i manjeg apsolutnog broja umrlih (2018. godine 32 žene, 2017. godine 21 žena). Najvišu razinu stopa je dosegla 2012. godine (17,3/100 000), a najnižu 2013. godine (8,1/100 000). Razina županijske stope smrtnosti cijelo promatrano razdoblje isprepliće se s europskom i republičkom razinom ${ }^{19,20}$. U razdoblju od 2014. do 2018. godine od karcinoma dojke umrlo je i 7 muškaraca8.

Standardizirana stopa smrtnosti od zloćudnih novotvorina dušnika, dušnica i pluća znatno je niža u zemljama Europske unije (od 37,1/100 000 u 2009. do 35,2/100 000 u 2015. godini) u odnosu na Hrvatsku i Županiju (slika 10).

Ovo sijelo raka izravno je povezano s pušenjem kao vodećim rizikom. Stopa smrtnosti od raka dušnika, dušnica i pluća u Primorsko-goranskoj županiji ima blago uzlazni trend i kreće se od 44,5/100 000 u 2009. do 44,7/100 000 u 2018. godini te se u cijelom promatranom razdoblju isprepliće s republičkom stopom koja pokazuje blago silazni trend.

Unutar druge skupine Međunarodne klasifikacije bolesti i srodnih stanja (MKB-10) u Primorsko-goranskoj županiji za većinu smrti odgovorne su zloćudne novotvorine dušnika, dušnica i pluća. Stopa smrtnosti muškaraca od zloćudnih novotvorina dušnika, dušnica i pluća u svim subregijama značajno je veća u odnosu na stope smrtnosti kod žena ${ }^{20}$.

Rak debelog i završnog crijeva nalazi se među tri najčešća sijela raka u Primorsko-goranskoj županiji (slika 11). 
Prema prosjeku, Županija je lošija od Europske unije, ali bolja od Republike Hrvatske. Nagli skok u 2018. godini još je predmet proučavanja.

U Primorsko-goranskoj županiji vanjski uzroci smrti (padovi, namjerna samoozljeđivanja, nezgode pri prijevozu...) na trećem su mjestu uzroka smrti. U promatranom razdoblju 2014. - 2018. veću stopu smrtnosti od vanjskih uzroka smrti po spolu imaju muškarci, osim 2016. godine ${ }^{20}$.

Zbog relativno malog broja umrlih od prometnih nesreća (2018. umrlo 17 stanovnika, godinu ranije 27), njihove stope znatno osciliraju, $i$ to sa silaznim trendom. Primorsko-goranska županija i Hrvatska bilježe višu stopu smrtnosti od prometnih nesreća od europskog prosjeka, gdje se stopa kreće od 6,6/100 000 u 2009. godini do 4,5/100 000 u 2015. godini. Od 2014. $(10,6 / 100000)$ do 2016 . $(5,35 / 100000)$ stopa u Županiji pokazuje strmi pad, a 2018. godine vrijednost joj je najniža $(5,1 / 100000)$ u promatranom razdoblju (slika 12). Samoubojstva su najveći uzrok prijevremenih smrti u većini razvijenih zemalja. Razina smrtnosti zbog samoubojstva u Primorsko-goranskoj županiji viša je od europskog prosjeka, a niža od hrvatskog (slika 13).

Izuzetak su 2011. i 2015. godina, kada stopa pokazuje najvišu vrijednost 14,5/100 000. Stopa zatim pada na 11,1/100000 u 2017. godini, odnosno na 12/100 000 u 2018. U Primorsko-goranskoj županiji samoubojstvo je bilo uzrok smrti 48 stanovnika, a godinu dana ranije 39 stanovni$\mathrm{ka}^{20}$.

Prijevremene su smrti sve one prije prosječnog očekivanog trajanja života. Takvih je u PGŽ-u u 2018. godini bilo 1677, s 22739 izgubljenih godina života. Vodeći uzroci smrti s najviše izgubljenih godina života jesu novotvorine, kardiovaskularne bolesti i ozljede ${ }^{20}$.

U pet promatranih godina (2012. - 2016.) muškarci najčešće obolijevaju od raka prostate 2015. godine 160/100 000 muškaraca, zatim od dušnica i pluća 113/100 000 te karcinoma debelog crijeva 72/100 000 $22-26$. U istome je razdoblju dojka najčešće sijelo novotvorina kod žena. Stopa incidencije najmanja je u 2013. godini i iznosi 123/100 000. Na drugome se mjestu smjenjuju novotvorina debeloga crijeva i dušnica (bronha) i pluća ${ }^{21-25}$.

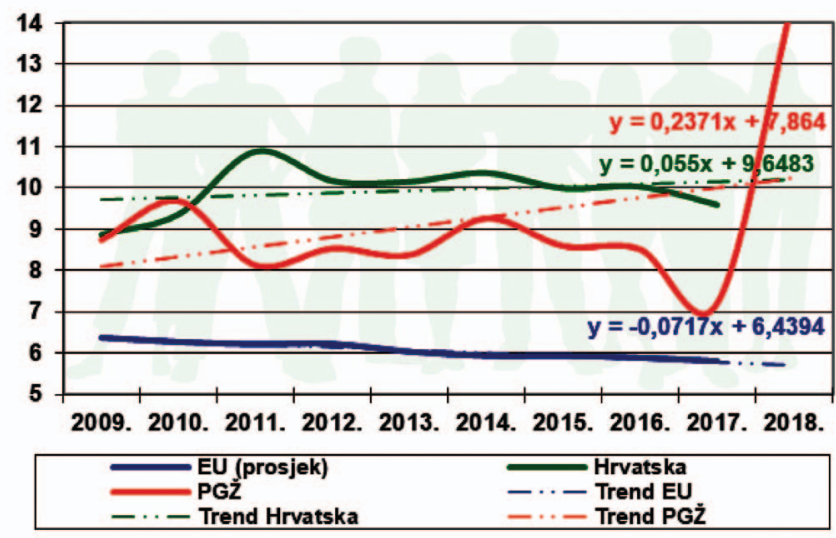

Slika 11. Standardizirana stopa smrtnosti od karcinoma debelog crijeva na 100000 stanovnika, PGŽ 2009. - 2018.

Izvor: European Health for All database, HZJZ/baza umrlih PGŽ-a

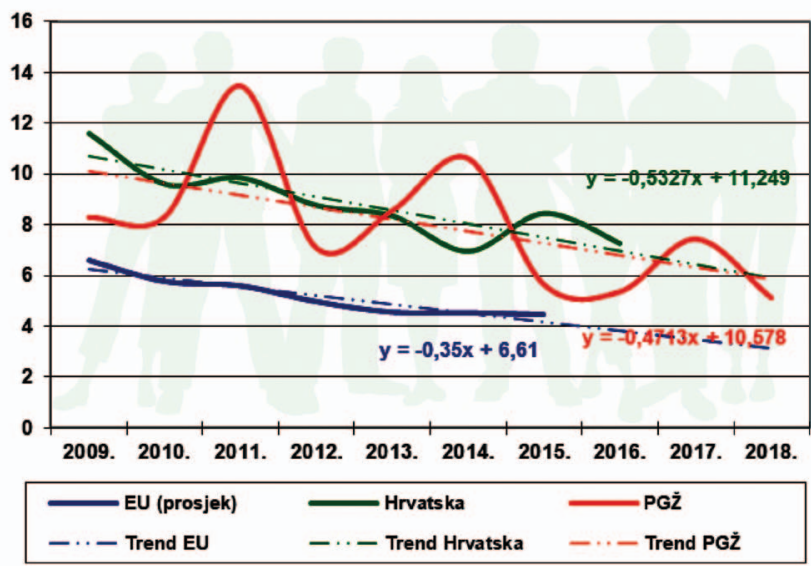

Slika 12. Standardizirana stopa smrtnosti zbog nezgoda pri prijevozu na 100000 stanovnika

Izvor: European health for All database, HZJZ/ baza umrlih PGŽ-a

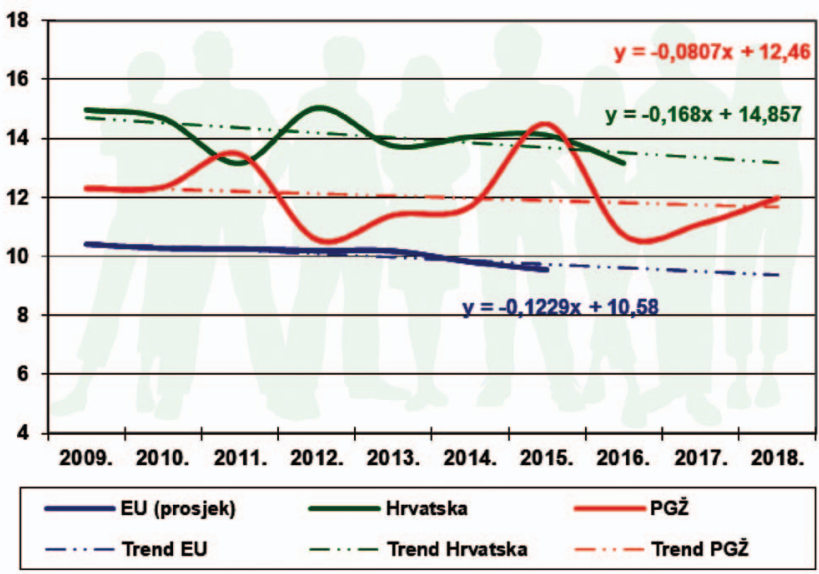

Slika 13. Standardizirana stopa smrtnosti od samoubojstva na 100000 stanovnika

Izvor: European health for All database, HZJZ/ baza umrlih PGŽ-a 


\section{RASPRAVA}

Jedna od važnijih funkcija javnog zdravstva jest funkcija procjene zdravlja i zdravstvenih potreba stanovništva. Suvremeno javno zdravstvo definira ocjenu zdravstvenih potreba složenije, s ciljem prepoznavanja i rješavanja zdravstvenih problema zajednice. Dobra procjena zdravstvenog stanja treba identificirati zdravstvene potrebe cjelokupnog stanovništva, dakle i skupina najvišeg rizika u populaciji. Javno zdravstvo shvaća pojam "zdravstvene potrebe" sveobuhvatno, a takvo shvaćanje izvire iz činjenice da je javno zdravstvo multiprofesionalno i multisektorsko.

Upravo zbog navedenog, multidimenzionalnost i potreba za zdravstvenom zaštitom samo je jedan od načina izražavanja zdravstvene potrebe.

Zadnjih dvadesetak godina hrvatsko javno zdravstvo uvelo je neke suvremene elemente u funkciju procjene zdravlja i zdravstvenih potreba stanovništva. To uključuje:

- evaluaciju rutinske i demografske statistike u procjeni zdravstvenih potreba

- uvođenje kvalitativne metodologije kao nove istraživačke paradigme

- identificiranje i ocjenu zdravstvenih potreba specifičnih populacijskih skupina

- intervencijski health survey, novi oblik istraživanja zdravstvenih potreba stanovništva ${ }^{3}$.

Zdravstveno stanje stanovnika ne ovisi isključivo o djelovanju zdravstvenog sustava i ne može se promatrati odvojeno od demografskih pokazatelja.

U socijalno-medicinskim analizama stanovništvo čini polaznu točku djelovanja. Iz demografskih pokazatelja evidentno je da starenje populacije ima uzlazni trend. Stanovništvo Republike Hrvatske ubraja se među najstarije u Europi, a prosječna starost žitelja Primorsko-goranske županije veća je od državnog prosjeka. Istovremeno, u promatranom desetogodišnjem razdoblju prirodni priraštaj stanovnika Županije, kao i svih njezinih subregija bio je negativan, što znači da je umiranje bila učestalija pojava od rađanja.

U zdravstvenim pokazateljima istaknuti su vodeći uzroci smrti, kao najpouzdaniji podatci o zdravstvenom stanju populacije. Vodeće grupe uzroka smrti i dalje se ne razlikuju od onih u Republici Hrvatskoj i zemljama Europske unije. U nekim grupama uzroka smrti Primorsko-goranska županija bliže je europskom prosjeku (npr. smrtnost od kardiovaskularnih i cerebrovaskularnih bolesti u dobi do 65 godina starosti). Razina smrtnosti prikazana je očekivanim trajanjem života. U 2018. godini očekivano trajanje života u Županiji bilo je veće od republičkog. Rak je značajan javnozdravstveni problem. Drugi je najvažniji uzrok smrti iza bolesti srca i krvnih žila. Stopa smrtnosti od novotvorina veća je u našoj Županiji u odnosu na europski prosjek i Hrvatsku, što je u najvećoj mjeri rezultat produženog očekivanog trajanja života, odnosno sve većeg broja osoba koje dosežu visoke godine života u kojima se maligne bolesti češće pojavljuju. Novotvorina dojke, kao najčešćega sijela kod žena, dobar je primjer kako se više od $90 \%$ bolesnica s rakom dojke može uspješno izliječiti ako se dijagnoza bolesti postavi u ranom stadiju i ispravno liječi, za što su stručna društva izradila smjernice ranog otkrivanja raka dojke kojima preporučuju mamografiju kao metodu probira njegovog ranog otkrivanja. Petogodišnje preživljavanje u tom slučaju iznosi $97 \%{ }^{9}$. Potrebno je povećati svjesnost populacije o važnosti redovitih preventivnih pregleda, kao i dostupnih metoda ranog otkrivanja raka te povećati razinu zdravstvene prosvijećenosti.

Velik broj kroničnih nezaraznih bolesti, bolesti su nezdravog, suvremenog načina života. Obilježava ih dugotrajan tijek (često su doživotne), mogu smanjiti kvalitetu života te dovesti do invalidnosti i prijevremene smrti. Značajno opterećuju zdravstveni sustav. Kardiovaskularne bolesti vodeći su uzrok pomora u Primorsko-goranskoj županiji. Dob u kojoj se bolest dijagnosticira sve je niža. Većina kardiovaskularnih bolesti može se prevenirati djelovanjem na faktore rizika (pušenje, nezdrava prehrana, pretilost, tjelesna neaktivnost, visok krvni tlak). Pad smrtnosti od kardiovaskularnih bolesti rezultat je dobro organizirane zdravstvene zaštite, kurativne i preventivne, u kojoj intervencije u smislu promocije zdravlja i prevencije bolesti kao strategije zbrinjavanja ovog javnozdravstvenog problema pronalaze svoje mjesto.

Podatak koji nas potiče na razmišljanje i ulaganje u zdravlje jest podatak o prijevremenoj smrti i izgubljenim godinama života. Novotvorine su prvi 
uzrok izgubljenih godina života, zatim slijede kardiovaskularne bolesti te ozljede. Međutim, od ova tri uzroka smrti najveći broj godina po jednoj smrti odnose ozljede, zatim novotvorine pa kardiovaskularne bolesti. Prometne nesreće jedan su od vodećih uzroka izgubljenih potencijalnih godina života jer su najčešće u mlađoj životnoj dobi. Primjenjujući određenu preventivnu strategiju i promociju sigurnosti u prometu, prometne se nesreće mogu smanjiti i do $75 \%$. Prikazani podatci ukazuju na područje u kojem preventivni programi i promocija zdravog načina života nalaze svoje mjesto.

Prosperitet i napredak društva ogleda se u ulaganju u zdravlje, no naglasak nije na kurativi, odnosno liječenju bolesti, već preventivi, odnosno sprječavanju bolesti. $U$ tom segmentu veliku ulogu ima javno zdravstvo i aktivnosti koje se provode u okviru javnozdravstvenih programa i različitih aktivnosti. Četiri nacionalna programa, proizašla iz Primorsko-goranske županije, odnosno Nastavnog zavoda za javno zdravstvo PGŽ-a, jesu nacionalni programi ranog otkrivanja raka dojke, ranog otkrivanja raka debelog crijeva, ranog otkrivanja raka vrata maternice te Nacionalni program unaprjeđenja oralnog zdravlja djece, koji su se prvotno provodili kao županijski programi u PGŽ-u, da bi kasnije prerasli u uspješne nacionalne programe. Zadaća je svih tih programa prevencija bolesti i unaprjeđenje zdravlja stanovnika, podizanje svjesnosti o zdravlju, odnosno shvaćanja da je dobro zdravlje rezultat provođenja zdravih životnih navika, pri čemu građani ne smiju biti samo pasivni promatrači svoga zdravstvenog stanja, već njegovi aktivni kreatori.

\section{ZAKLJUČCI}

Iz navedenih podataka možemo zaključiti:

- da populacija u Primorsko-goranskoj županiji stari

- stopa nataliteta u padu je, a stopa mortaliteta u porastu, što uzrokuje depopulaciju u Županiji

- vodeći uzroci smrti u Županiji jesu kardiovaskularne bolesti, čija je stopa u laganome padu

- novotvorine su drugi uzrok smrti i po njima smo znatno lošiji od Europske unije, ali i od
Republike Hrvatske; županijska stopa u laganome je porastu

- vodeći uzroci smrti od novotvorina kod muškaraca su dušnik, dušnice i pluća, nakon toga debelo crijevo

- vodeći uzrok smrti od novotvorina kod žena je dojka, nakon toga dušnik, dušnice i pluća, pa debelo crijevo

- od vanjskih uzroka smrti (nezgode) umire više muškaraca

- od nezgoda u prijevozu standardizirana stopa smrtnosti bliska je republičkoj, ima silazni trend, ali je znatno lošija od Europske unije

- standardizirana stopa smrtnosti od samoubojstava niža je od republičke, ali viša od stope u Europskoj uniji; u promatranome razdoblju oscilira zbog relativno malog broja samoubojstava

- najveći udio u prijevremenim smrtima uzrokuju novotvorine, kardiovaskularne bolesti i ozljede

- od svih novotvorina - muškarci najčešće obolijevaju od raka prostate, a žene od raka dojke.

Izjava o sukobu interesa: Autori izjavljuju kako ne postoji sukob interesa.

\section{LITERATURA}

1. World Health Organisation. Constitution of the World Health Organization. World Health Organization Handbook of basic documents. $5^{\text {th }}$ Edition. Geneva: WHO, 1952.

2. Oortwijn W, Nelissen E, Adamini S, van den Heuvel $S$, Geuskens G, Burdof L. Social determinants state of the art reviews - Health of people of working age - Summary Report. Luxembourg: European Commission Directorate General for Health and Consumers; 2011.

3. Jakšić Ž., Kovačić L i sur. Socijalna medicina. Zagreb: Medicinska naklada, 2000.

4. Državni zavod za statistiku Republike Hrvatske. Naselja i stanovništvo Republike Hrvatske. Broj stanovnika po općinama/gradovima, popis 1991. [Internet]. Zagreb: Državni zavod za statistiku Republike Hrvatske; 2013. [cited 2019 May 11]. Dostupno na: https://www.dzs.hr/ PXWeb/Table.aspx?layout=tableViewLayout1\&px tableid=Tabela3_08.px\&px_path=Naselja\%20i\%20 stanovni\%c5\%a1tvo\%20Republike\%20 Hrvatske Stanovni\%c5\%a1tvo__Gradovi\%20i\%20 Op\%c4\%87ine\&px_language $=\mathrm{hr} \& \mathrm{px} \_\mathrm{db}=$ Naselja $\% 20$ i\%20stanovni\%c5\%a1tvo\%20Republike\%20 Hrvatske\&rxid=fc9d580f-2229-4982-a72c-cdd3e96307d3.

5. Državni zavod za statistiku Republike Hrvatske. Popis stanovništva 2001. Stanovništvo prema spolu i starosti, po naseljima, popis 2001. [Internet]. Zagreb: Državni za- 
vod za statistiku Republike Hrvatske; 2001. [cited 2019 Jun 11]. Dostupno na: https://www.dzs.hr/Hrv/censuses/Census2001/Popis/H01_01_02/h01_01_02_zup08. htm.

6. Državni zavod za statistiku Republike Hrvatske. Popis stanovništva, kućanstava i stanova 2011. Stanovništvo prema spolu i starosti. Statističko izvješće br. 1468. [Internet]. Zagreb: Državni zavod za statistiku Republike $\mathrm{Hr}$ vatske; 2013. [cited 2019 Sep 15]. Dostupno na: https:// www.dzs.hr/Hrv_Eng/publication/2012/SI-1468.pdf.

7. Državni zavod za statistiku Republike Hrvatske. Procjene stanovništva Republike Hrvatske u 2018. Priopćenje br 7.1.3. [Internet]. Zagreb: Državni zavod za statistiku Republike Hrvatske; 2019 [cited 2019 Sep 30]. Dostupno na: https://www.dzs.hr/Hrv_Eng/publication /2019/07-01-03_01_2019.htm.

8. Zdravstveno-statistički ljetopis PGŽ za 2018. godinu [Internet]. Rijeka: Nastavni zavod za javno zdravstvo Primorsko-goranske županije; 2019. [cited 2018 Dec 16]. Dostupno na: http://www.zzjzpgz.hr/statistika/statistika2018/pdf/1.pdf.

9. Miler V, Buršić I. Prirodno kretanje stanovništva u 2009. Prirodno kretanje stanovništva u 2009. po županijama i općinama/gradovima. Statističko izvješće 1411. [Internet]. Zagreb: Državni zavod za statistiku Republike Hrvatske; 2010. [cited 2018 May 16]. Dostupno na: https:// www.dzs.hr/Hrv_Eng/publication/2010/SI-1411.pdf.

10. Miler V. Prirodno kretanje stanovništva Republike Hrvatske u 2010. Prirodno kretanje stanovništva u 2010. Priopćenje br. 7.1.1. [Internet]. Zagreb: Državni zavod za statistiku Republike Hrvatske; 2011. [cited 2018 May 16]. Dostupno na: https://www.dzs.hr/Hrv_Eng/publication/2011/07-01-01_01_2011.htm.

11. Miler V, Buršić I. Prirodno kretanje stanovništva u 2011. Prirodno kretanje stanovništva u 2011. po županijama i općinama/gradovima. Statističko izvješće 1466. [Internet]. Zagreb: Državni zavod za statistiku Republike Hrvatske; 2012. [cited 2018 May 16]. Dostupno na: https:// www.dzs.hr/Hrv_Eng/publication/2012/SI-1466.pdf.

12. Miler V, Lasan I. Prirodno kretanje stanovništva Republike Hrvatske u 2012. Prirodno kretanje stanovništva u 2012. Priopćenje br. 7.1.1. [Internet]. Zagreb: Državni zavod za statistiku Republike Hrvatske; 2013. [cited 2018 May 16]. Dostupno na: https://www.dzs.hr/Hrv_Eng/ publication/2013/07-01-01_01_2013.htm.

13. Lasan I, Miler V. Prirodno kretanje stanovništva Republike Hrvatske u 2013. Prirodno kretanje stanovništva u 2013. Priopćenje br. 7.1.1. [Internet]. Zagreb: Državni zavod za statistiku Republike Hrvatske; 2014. [cited 2018 May 16]. Dostupno na: https://www.dzs.hr/Hrv_Eng/ publication/2014/07-01-01_01_2014.htm.

14. Lasan I, Miler V. Prirodno kretanje stanovništva u 2014. Prirodno kretanje stanovništva u 2014. po županijama i općinama/gradovima. Statističko izvješće 1542. [Internet]. Zagreb: Državni zavod za statistiku Republike Hrvatske; 2015. [cited 2018 May 16]. Dostupno na: https:// www.dzs.hr/Hrv_Eng/publication/2015/SI-1542.pdf.

15. Miler V. Prirodno kretanje stanovništva Republike Hrvatske u 2015. Prirodno kretanje stanovništva u 2015. Priopćenje br. 7.1.1. [Internet]. Zagreb: Državni zavod za statistiku Republike Hrvatske; 2016. [cited 2018 May 16]. Dostupno na: https://www.dzs.hr/Hrv_Eng/publication/2016/07-01-01_01_2016.htm.

16. Radić T, Zebec A. Prirodno kretanje stanovništva u 2016. Prirodno kretanje stanovništva u 2016. po županijama i općinama/gradovima. Statističko izvješće 1596. [Internet]. Zagreb: Državni zavod za statistiku Republike Hrvatske; 2017. [cited 2018 May 16]. Dostupno na: https:// www.dzs.hr/Hrv_Eng/publication/2017/SI-1596.pdf.

17. Zebec $A$, Miler V, Stolnik G. Prirodno kretanje stanovništva u 2017. Prirodno kretanje stanovništva u 2017. po županijama i općinama/gradovima. Statističko izvješće 1618. [Internet]. Zagreb: Državni zavod za statistiku Republike Hrvatske; 2018. [cited 2018 Dec 16]. Dostupno na: https://www.dzs.hr/Hrv_Eng/publication/2018/SI-1618. pdf.

18. Zebec A, Stolnik G. Prirodno kretanje stanovništva Republike Hrvatske u 2018. Prirodno kretanje stanovništva u 2018. Priopćenje br. 7.1.1. [Internet]. Zagreb: Državni zavod za statistiku Republike Hrvatske; 2019. [cited 2019 Oct 16]. Dostupno na: https://www.dzs.hr/Hrv_Eng/publication/2019/07-01-01_01_2019.htm.

19. World Health organization Regional Office for Europe. European Health for all Database (HFA-DB). [Internet]. Updated: October 2019. [cited 2020 Jan 17]. Dostupno na: https://gateway.euro.who.int/en/hfa-explorer/.

20. Hrvatski zavod za javno zdravstvo. Odjel za mortalitetnu statistiku. Služba za epidemiologiju i prevenciju kroničnih nezaraznih bolesti. Baza uzroka smrti za Primorsko-goransku županiju 2009.-2018.

21. Hrvatski zavod za javno zdravstvo. Registar za rak Republike Hrvatske. Incidencija raka u Hrvatskoj 2016. Bilten 41, Zagreb, 2019.

22. Hrvatski zavod za javno zdravstvo. Registar za rak Republike Hrvatske. Incidencija raka u Hrvatskoj 2015. Bilten 40, Zagreb, 2018.

23. Hrvatski zavod za javno zdravstvo. Registar za rak Republike Hrvatske. Incidencija raka u Hrvatskoj 2014. Bilten 39, Zagreb, 2016.

24. Hrvatski zavod za javno zdravstvo. Registar za rak Republike Hrvatske. Incidencija raka u Hrvatskoj 2013. Bilten 38, Zagreb, 2015.

25. Hrvatski zavod za javno zdravstvo. Registar za rak Republike Hrvatske. Incidencija raka u Hrvatskoj 2012. Bilten 37, Zagreb, 2014. 